\title{
Retroperitoneal panniculitis
}

\author{
Norihiko Terada, ${ }^{1,2}$ Takamasa Tanaka, $^{2}$ Takushi Fujimoto, ${ }^{2}$ Yasuharu Tokuda ${ }^{3}$
}

${ }^{1}$ Mito Kyodo General Hospital, Mito City, Japan

${ }^{2}$ Kitano Hospital, Osaka, Osaka, Japan

${ }^{3}$ Department of General Internal Medicine, Tsukuba University, Mito, Ibaraki, Japan

\section{Correspondence to} Professor Yasuharu Tokuda, yasuharu.tokuda@gmail.com

Accepted 8 October 2015

\section{CrossMark}

To cite: Terada $\mathrm{N}$, Tanaka T, Fujimoto T, et al. BMJ Case Rep Published online: [please include Day Month Year] doi:10.1136/ bcr-2015-212670

\section{DESCRIPTION}

A 21-year-old Japanese woman developed acute onset of persistent epigastric pain and nausea, and presented to the emergency department $12 \mathrm{~h}$ after the onset of symptoms. There was no significant medical history, nor was there allergy, significant family history, recent travel or trauma, and she had not undergone any particular change in eating habits. On examination, she was in acute distress; the blood pressure was $124 / 75 \mathrm{~mm} \mathrm{Hg}$, pulse $90 \mathrm{bpm}$, respiration 20 breaths/min and temperature $37.4^{\circ} \mathrm{C}$. The abdomen was soft and flat, but with positive Mallet-Guy sign (tenderness of left upper quadrant palpation with the patient lying in a right lateral decubitus position). Peripheral white cell count was $1.5 \times 10^{10} / \mathrm{L}$. Renal and liver functions were normal. A diagnosis of acute pancreatitis was suspected and the patient was started on volume replacement and loxoprofen. However, serum lipase and amylase levels were normal and the CT of the abdomen revealed a high-density lesion behind the pancreas, within the retroperitoneal space (figure 1). On day 4, MR cholangiopancreatography showed an increased signal density of retroperitoneal fat (figure 2). A diagnosis of retroperitoneal panniculitis was considered. The abdominal pain gradually disappeared and white cell count returned to normal $\left(7.8 \times 10^{9} / \mathrm{L}\right)$ on day 4 .

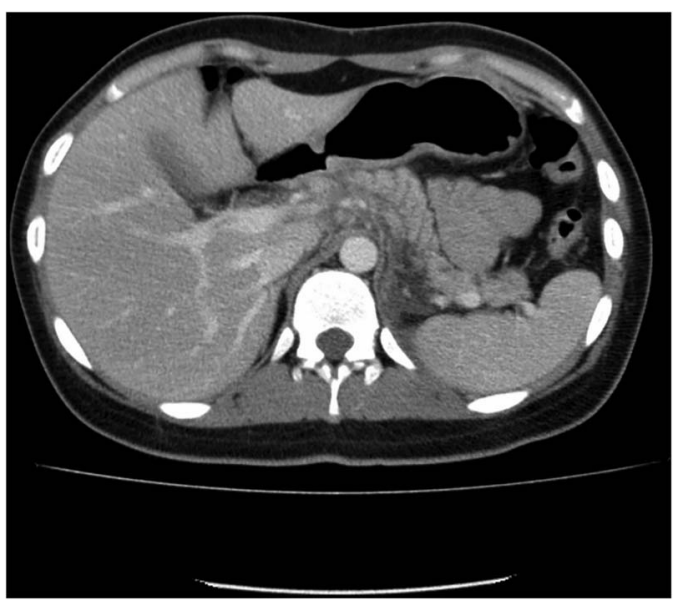

Figure $1 \mathrm{CT}$ of the abdomen revealing a high-density lesion behind the pancreas, within the retroperitoneal space.

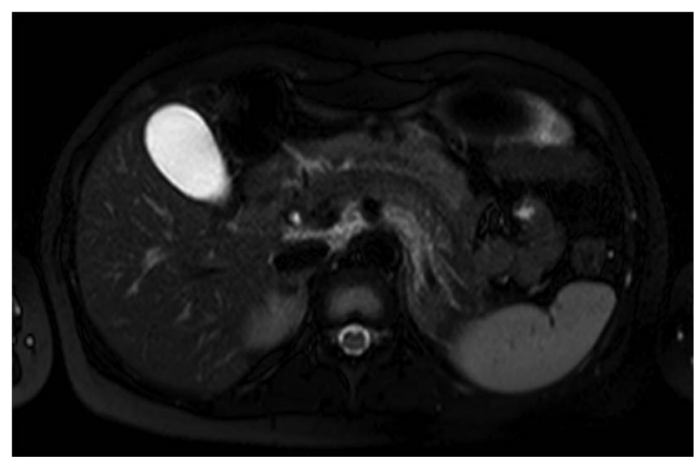

Figure 2 MR cholangiopancreatography showing abnormal signal density within retroperitoneal fat tissue.

The patient was discharged on day 7. Although abdominal panniculitis is usually recognised in mesenteric fat tissue, few cases with retroperitoneal panniculitis have been previously reported. ${ }^{1}$ While causes of abdominal panniculitis may include infectious, neoplastic or autoimmune diseases, ${ }^{2}$ our case was considered to have an idiopathic cause because of the self-limited course.

\section{Learning points}

- Causes of acute abdominal pain with positive Mallet-Guy sign may include retroperitoneal panniculitis in addition to acute pancreatitis.

- Abdominal panniculitis may involve not only mesenteric fat, but also retroperitoneal space.

Contributors NT, TT and TF cared for the patient. NT and YT wrote the manuscript.

Competing interests None declared.

Patient consent Obtained.

Provenance and peer review Not commissioned; externally peer reviewed.

\section{REFERENCES}

1 McCrystal DJ, O'Loughlin BS, Samaratunga H. Mesenteric panniculitis: a mimic of malignancy. Aust N Z J Surg 1998;68:237-9.

2 Issa I, Baydoun H. Mesenteric panniculitis: various presentations and treatment regimens. World J Gastroenterol 2009;15:3827-30. 
Copyright 2015 BMJ Publishing Group. All rights reserved. For permission to reuse any of this content visit http://group.bmj.com/group/rights-licensing/permissions.

BMJ Case Report Fellows may re-use this article for personal use and teaching without any further permission.

Become a Fellow of BMJ Case Reports today and you can:

- Submit as many cases as you like

- Enjoy fast sympathetic peer review and rapid publication of accepted articles

- Access all the published articles

- Re-use any of the published material for personal use and teaching without further permission

For information on Institutional Fellowships contact consortiasales@bmjgroup.com

Visit casereports.bmj.com for more articles like this and to become a Fellow 